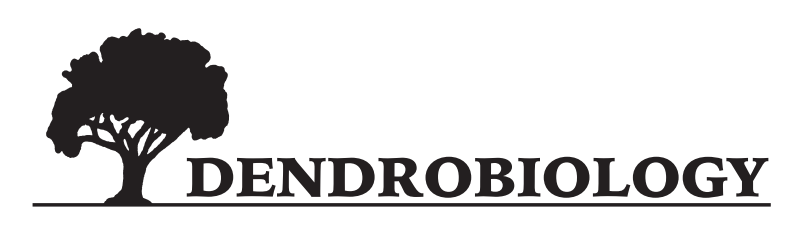

2016, vol. 75, 13-21

http://dx.doi.org/10.12657/denbio.075.002

\author{
Min Dong, YouMing Xu*, Han Lin, XueQin Li, QingQing Xia
}

\title{
Seasonal dynamics in cambial activity and the formation of xylem and phloem in the branches of Cinnamomum camphora
}

Received: 9 January 2015; Accepted: 4 September 2015

\begin{abstract}
The cambial activity and periodicity of secondary xylem and phloem formation have been less studied in tropical tree species than in temperate ones. Cambium activity is the only source of timber production. Studies on its activity and xylem formation can provide helpful data for dendrochronology and possible factors that control tree growth, the yield and quality of wood. Cinnamomum camphora is an important fast-growing tree for furniture and sculpture wood in South China. Its dynamics of cambial activity was not reported. During the growth season in 2011, five trees of Cinnamomum camphora plantation were monitored on the campus of Huazhong Agricultural University in central china (located on $113^{\circ} 41^{\prime}$ to $115^{\circ} 05^{\prime} \mathrm{E}$ and $29^{\circ} 58^{\prime}$ to $31^{\circ} 22^{\prime}$ N). Sampling time was from 13, February 2011 to 13, February 2012. Some small stems of 15-20 cm length were selected to sample in the middle of 2-3 years old health branches in the central crown of these trees. The observational study found that the cambium of camphor trees was active from March to October and dormant from November to February. Onset of cambial cell division was observed in early March, one week after sprouting of new buds. The morphology of the cells and number of cell layers in the cambium zone varied throughout the year. In early March, cambium reactivated with the rising of temperature, the cell wall was relative thick. The number of cell layers increased from 2-3 in middle Feb. to $3-5$. In June, the number of cell layers in cambium reached the maximum of 5-7 in a radial direction. In mid March, phloem cells began to differentiate, followed by xylem three weeks later. The number of cell layers in immature phloem and xylem increased dramatically before mid June and the increment of cell layers in xylem was almost fifth times of phloem in the differentiating process. The phloem cells mainly stopped dividing new cells in end of October, but xylem cells were still in the activity a week later. The annual activities of cambium was in accordance with the air mean temperature change in 2011-2012. The results showed that the cambial activity and formation of xylem and phloem were related to the environmental factors, especially the temperature.
\end{abstract}

Keywords: Cinnamomum camphora, cambium, xylem, phloem, wood formation, phenological characteristics

Address: M. Dong, Y.M. Xu, H. Lin, X.Q. Li, Q.Q. Xia, College of Horticulture \& Forestry Sciences, Huazhong Agricultural University, Wuhan 430070, China, e-mail: xuyouming@mail.hzau.edu.cn 


\section{Introduction}

Wood formation begins with periclinal cell divisions in the vascular cambium of trees, followed by cell differentiation (Gričar et al., 2007b). The cambium activity and cell differentiation provide not only information about the age of trees (Callado et al., 2003; Worbes et al., 2003), but also clues about the possible factors controlling tree growth, the yield and quality of wood (Dave \& Rao, 1982; Ohashi et al., 2001; Venugopal \& Liangkuwang, 2007; Fonti et al., 2010; Krepkowski et al., 2011; Gričar \& Jagodic, 2014), which are helpful in knowing wood formation, predicting timber and biomass yield, and in determining forest dynamics. In recent years, a series of studies have dealt with the seasonal cambial activity and wood formation in various tree species. The broad-leaf species, such as Robinia pseudoacacia (Derr \& Evert), Acer negundo (Tucker et al., 1969), Cedrela fissilis (Marcati et al., 2006), Castanea sativa (Cufar et al., 2011), Fagus orientalis (Oladi et al., 2011). The coniferous trees, such as Abies balsamea (Deslauriers et al., 2003), Pinus halepensis (Deluis et al., 2007), Pinus sylvestris (Schmitt et al., 2004),etc. Recent reports on wood formation at a cellular level have confirmed the significance of the knowledge for dendroclimatological and dendroecological studies(Gričar et al., 2007a; Marion et al., 2007; Čufar et al., 2008; Mäkinen et al., 2008).

Cambial activity is regulated both by internal signals and environmental factors (Schweingruber, 1988). Day length and temperature were the main environmental factors influencing the seasonal cambium activity (Oliveira et al., 2009). The majority of past studies usually focused on trees growing in tem- perate region with definite seasonal climate (Derr \& Evert, 1967; Evert \& Deshpande, 1970; Antonova \& Stasova, 2006; Eilmann et al., 2009; Gričar et al., 2009; Chen et al., 2010; González-González \& GarcíaGonzález, 2013). Studies about wood formation in subtropical and tropical species are rare, where the climate seasonality and annual ring growth formation are less obvious (Worbes, 1999).

Cinnamomum camphora (L.) Presl (Lauraceae: Cinnamomum) is one of the most common species in subtropical evergreen broad-leaved forest in China, primarily distributing in the South of Yangtze river. The camphor tree grows well with sufficient light and rainfall in this region. It is one of the fast growing tree species and its wood usually shows us a diffuse or near semi-ring porous type. It is an important wood species for furniture and sculpture with high economic value in China. Its dynamics of cambial activity was not reported. This paper presents a study of seasonal dynamics of cambial activity in the branches of camphor trees in 2011-2012. The relationship between seasonal cambial activity, xylem and phloem growth ring formation, tree phenology as well as weather conditions were investigated. These will offer a scientific basis for better understanding of wood formation mechanisms, cultivation and wood resources utilization, as well as dendroclimatological and dendroecological studies, basic data for plant anatomy theories.

\section{Methods}

The study site is in a plantation of camphor trees on the campus of Huazhong Agricultural Universi-

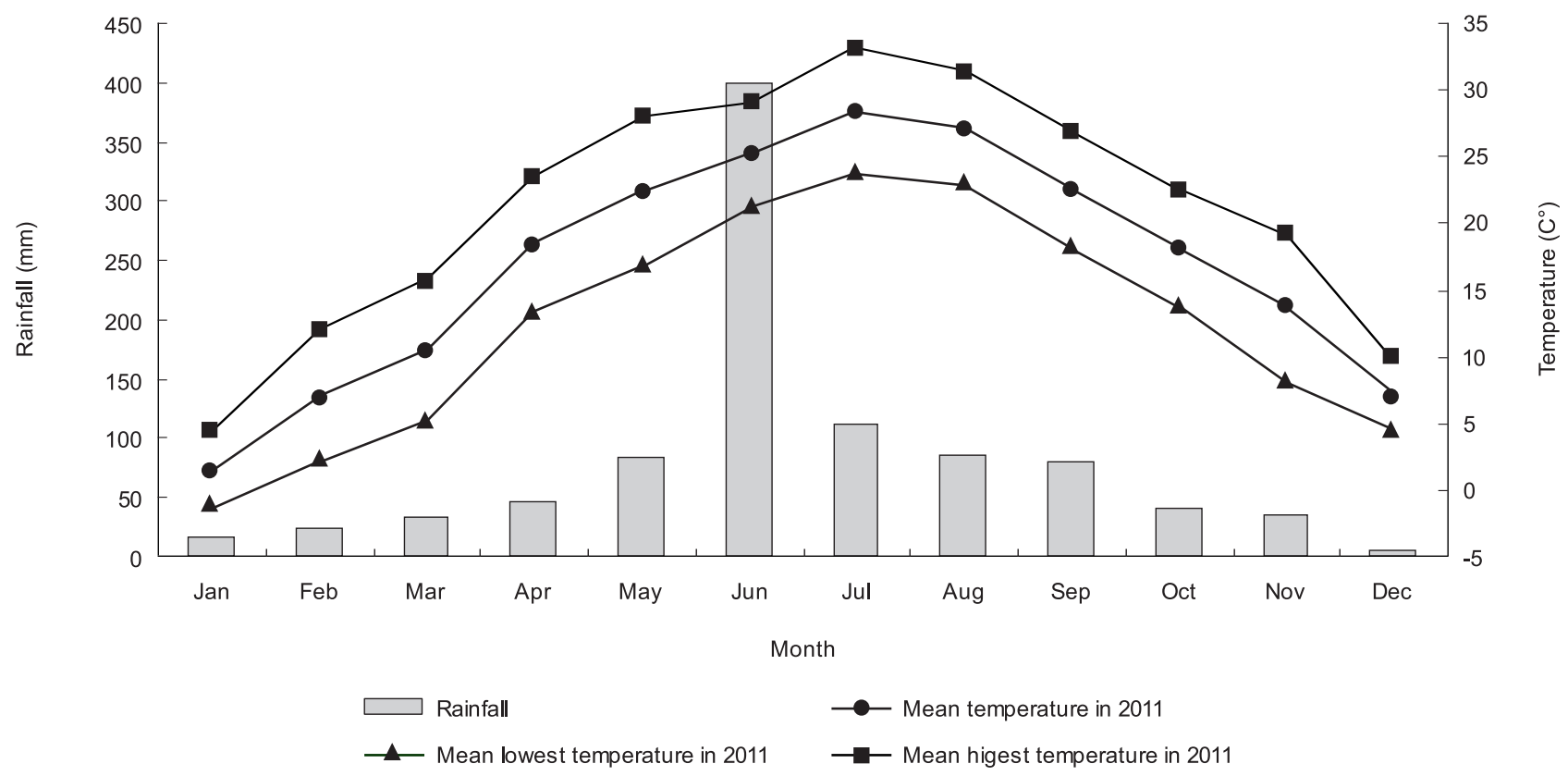

Fig. 1 Climate diagram of 2011 in Wuhan meteorological station 
ty, located in Wuhan $\left(113^{\circ} 41^{\prime}-115^{\circ} 05^{\prime} \mathrm{E}, 2^{\circ} 58^{\prime}-\right.$ $31^{\circ} 22^{\prime} \mathrm{N}$ ), Hubei province in 2011 . It has a typically subtropical humid monsoon climate with a hot and rainy summer and a cold winter. According to the records in Wuhan meterological station, the average annual sum of precipitation was $966.4 \mathrm{~mm}$ in 2011 , mostly concentrating in June. The annual average temperature was $16.8^{\circ} \mathrm{C}$ in 2011 , with the highest in July (average temperature $28.4^{\circ} \mathrm{C}$ ) and lowest in January (average temperature $1.6^{\circ} \mathrm{C}$ ) (Fig. 1).

Five healthy trees were selected in the camphor plantation on the campus for sampling study, with the mean diameters of $20 \mathrm{~cm}$, height of $9 \mathrm{~m}$ and age of 10 years. Five branches per time were collected from the central crown of each tree with high branch scissors, which including the current, one-year-old, and two-year-old ones. Samples of branches were collected in weekly intervals between 13 February 2011 and 28 July 2011 and bi-weekly between 28 July 2011 and 13 February 2012. The reaction-wood was not chosen. Phenological data (leaf growth, leaf fall, leaf flush, flowering and fruiting) was recorded during this period.

The branches cutted into short sections with small pruning shears were fixed in FAA (formalin-aceto-alcohol) solution immediately, then vacuumed $30 \mathrm{~min}$. Highly lignified branches were softened in HF (hydrofluoric acid) (generally 2 weeks, longer in winter) because of the high hardness. Finally the materials were treated as following: dehydrating in gradient alcohol (30\%, 50\%, 70\%, 85\%, 90\% and 100\%), transparenting in xylene, embedding in paraffin, then using a YL 3A Rotary Microtome for sectioning into thin slices $(8-15 \mu \mathrm{m})$. 30 sections were gotten from each sample. These sections were stained with $1 \%$ phenylamine-sarranine $1 \mathrm{~h}$ and phenylamine-fast green $4-5 \mathrm{~s}$. 3 better sections with higher clear quality were selected for taking picture.

A VNT NB591 transflective metallographic microscope and the Quantlab-ST image analysis software were used for anatomical observations and semi-automatic counting and measuring of cells and tissues at various stages of their development. The developing cells in xylem and phloem of the cambium and their total number were counted on the 30 transverse sections of each sample in a tree. In the radial direction the cell layer number of cambium, xylem and phloem were recorded. The radial dimension of cambial cells and the thickness of cells were determined using these sections. The mean value were calculated from all data of each sample measured. Climatic factors such as monthly maximum, mean and minimum temperature; rainfall were figured. Anatomical variables such as cell layers of cambium, differentiating xylem and phloem, were comparatively also plotted. These figures were used for analyzing the relationship between climatic factors and cambial activity and determining the influence of particular climatic factor on cambial activity.

\section{Terminology}

1. Cambium cells or cambium zone: radial rows of fusiform and ray initials, including phloem and xylem mother cells.

2. Vascular cambium: several circle of flattened cells located between xylem and phloem.

3. Immature xylem: located in the internally to the cambium, the xylem forming during secondary growth from vascular cambium.

4. Immature phloem: located in the externally to the cambium, the phloem forming during secondary growth from vascular cambium.

\section{Results}

\section{Phenological characteristics}

Buds were open at the beginning of March, and displayed new leaves about a week later. Flowering was noticed in the months of April and May. Young fruit could be observed in late May. Buds germinated

Table 1. The cambium activity and phenology features of camphor trees during 2011-2012

\begin{tabular}{|c|c|c|c|c|c|}
\hline Sampling time & $\begin{array}{c}\text { Daily Air } \\
\text { temperature }\left({ }^{\circ} \mathrm{C}\right)\end{array}$ & $\begin{array}{c}\text { Cambium cell layer } \\
\text { number }\end{array}$ & Tissues differentiation & Phenological features & $\begin{array}{c}\text { Phases of } \\
\text { cambial acivity }\end{array}$ \\
\hline 2011.02 .13 & $-4-7$ & $2-3$ & - & No obivious features & Dormancy \\
\hline 2011.02 .20 & $2-14$ & $2-3$ & - & Bud swelling & Dormancy \\
\hline 2011.03 .01 & $2-8$ & $3-4$ & - & Bud sprouting & Reactivation \\
\hline 2011.03 .08 & $4-18$ & $3-4$ & - & Bud sprouting & Reactivation \\
\hline 2011.03 .13 & $6-16$ & $3-5$ & Phloem & Anthotaxy elongation & Reactivation \\
\hline 2011.03 .20 & $5-14$ & $3-5$ & Phloem & New leaf appearance & Reactivation \\
\hline 2011.03 .27 & $7-20$ & $3-5$ & Phloem & Leaf growing & Active \\
\hline 2011.04 .01 & $11-25$ & $3-5$ & Phloem & Leaf growing & Active \\
\hline 2011.04 .07 & $9-15$ & $3-5$ & Phloem + xylem & Leaf growing & Active \\
\hline 2011.04 .14 & $16-25$ & $3-5$ & Phloem + xylem & Leaf growing and flower & Active \\
\hline 2011.04 .21 & $15-21$ & $4-5$ & Phloem + xylem & Flower & Active \\
\hline
\end{tabular}


Min Dong et al.

\begin{tabular}{|c|c|c|c|c|c|}
\hline Sampling time & $\begin{array}{c}\text { Daily Air } \\
\text { temperature }\left({ }^{\circ} \mathrm{C}\right)\end{array}$ & $\begin{array}{c}\text { Cambium cell layer } \\
\text { number }\end{array}$ & Tissues differentiation & Phenological features & $\begin{array}{c}\text { Phases of } \\
\text { cambial acivity }\end{array}$ \\
\hline 2011.04 .28 & $20-31$ & $4-5$ & Phloem + xylem & Flower & Active \\
\hline 2011.05 .05 & $17-28$ & $4-5$ & Phloem + xylem & Flower & Active \\
\hline 2011.05 .12 & $19-29$ & $5-6$ & Phloem + xylem & Flower & Active \\
\hline 2011.05.19 & $24-35$ & $5-6$ & Phloem + xylem & Young fruit appearance & Active \\
\hline 2011.06 .02 & $19-30$ & $5-7$ & Phloem + xylem & Summer buds sprouting & Active \\
\hline 2011.06 .10 & $22-27$ & $5-7$ & Phloem + xylem & Full foliage & Active \\
\hline 2011.06 .17 & $22-29$ & $5-7$ & Phloem + xylem & Full foliage & Active \\
\hline 2011.06 .24 & $22-27$ & $5-7$ & Phloem + xylem & Full foliage and fruit & Active \\
\hline 2011.07 .01 & $26-34$ & $5-7$ & Phloem + xylem & Full foliage and fruit & Active \\
\hline 2011.07 .14 & $24-30$ & $5-7$ & Phloem + xylem & Full foliage and fruit & Active \\
\hline 2011.07 .28 & $28-36$ & $5-6$ & Phloem + xylem & Full foliage and fruit & Active \\
\hline 2011.08 .12 & $26-33$ & $4-6$ & Phloem + xylem & Full foliage and fruit & Active \\
\hline 2011.08 .25 & $21-28$ & $4-6$ & Phloem + xylem & Full foliage and fruit & Active \\
\hline 2011.09 .08 & $18-22$ & $3-5$ & Phloem + xylem & Full foliage and fruit & Active \\
\hline 2011.09 .28 & $20-28$ & $3-5$ & Phloem + xylem & Full foliage and fruit & Active \\
\hline 2011.10 .12 & $18-23$ & $2-4$ & Phloem + xylem & Full foliage and fruit & Transformation \\
\hline 2011.10 .27 & $11-16$ & $2-4$ & Phloem+xylem & Mature fruit & Transformation \\
\hline 2011.11 .11 & $8-19$ & $2-3$ & Xylem & Partial defoliation & Transformation \\
\hline 2011.11 .25 & $10-19$ & $2-3$ & Xylem & Partial defoliation & Dormancy \\
\hline 2011.12 .8 & $0-9$ & $2-3$ & - & Partial defoliation & Dormancy \\
\hline 2011.12 .21 & $1-10$ & $2-3$ & - & No obvious features & Dormancy \\
\hline 2012.01 .12 & $3-6$ & $2-3$ & - & No obvious features & Dormancy \\
\hline 2012.02 .13 & $3-6$ & $2-3$ & - & No obvious features & Dormancy \\
\hline
\end{tabular}

again and new branches grew in early June. Mature fruits were borne on tree from late October to December and parts of leaves fell in November. The exuberant growth period was happened from mid April to October, and the growth obviously slowed down from November to February (Table 1).

\section{Seasonal dynamics of cambial activity}

The vascular cambium of camphor tree reactivated completely and divided into new phloem and new xylem. Each new cell experienced several stages: (I) expansion or post-cambial growth, (II) secondary cell wall deposition followed by lignification and (III) programmed cell death.

Cambium produced secondary phloem outward and secondary xylem inward. The number and shape of each cell significantly changed in microscopic structure (Fig. 3). In mid Feb. the cambium was dormant and its cells were 2-3 layers (Table 1), as indicated by the arrow in Fig. 3. In early March, the 3-5 layers cambium cells had the characteristics of reactivation: cell radial diameter increased, cell tangential wall thinned and the cells were put in order

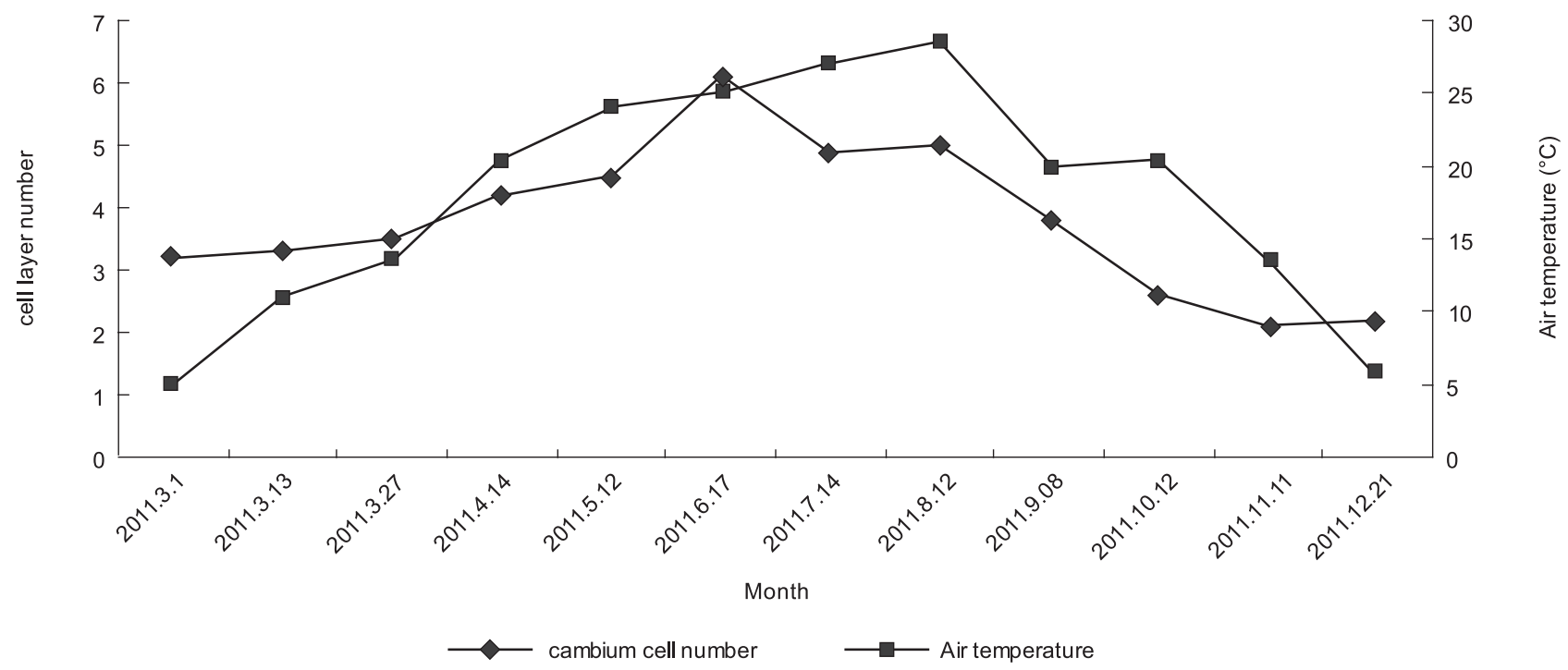

Fig. 2 Daily average air temperature and the number of of cell layer in cambium 
Seasonal dynamics in cambial activity and the formation of xylem and phloem in the branches...
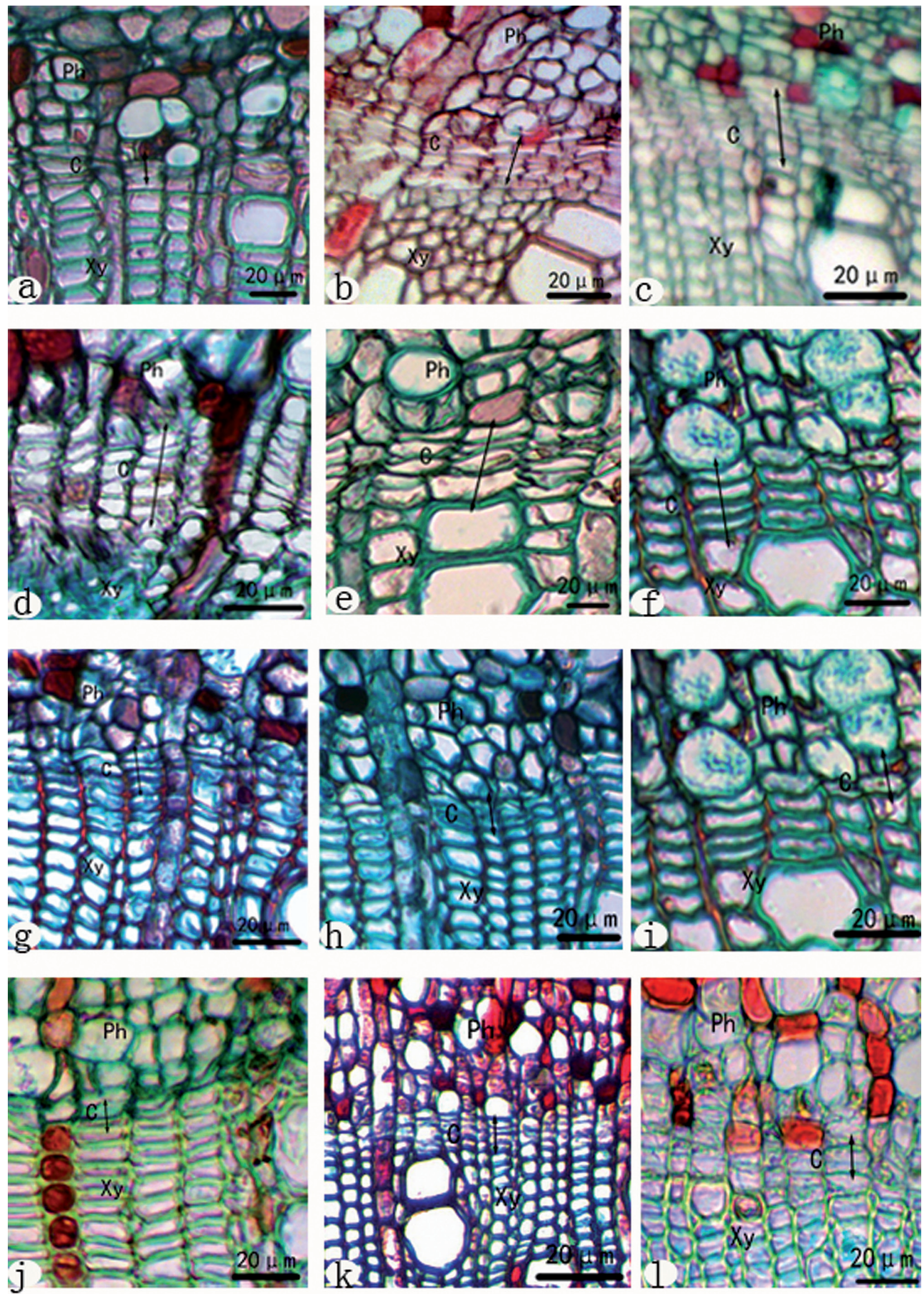

Fig. 3 Seasonal changes of vascular cambium cells 
in radial direction. During the active stage from the late March to October, the cambial zone was wider consisting of 3-7 cell layers in radial direction on sections (Fig. 2). In June, the number of cell layers in cambium reached the maxium of 5-7 layers (the arrow in Fig. 3d). In contrast, during the dormancy stage from November to February, the cambial zone was narrow, consisting of 2-3 layers with relatively thick radial walls (Table 1, Fig.2). At this stage the ray cells were filled with starch grains and oil cells (Fig. 3k).

\section{Relationship between phenology, climatic factors and cambial activity}

Cambium reactivated with the sprouting of buds in early March and the precipation was below $50 \mathrm{~mm}$ (Fig. 1) . The highest exuberant cambial activity could be observed in June and July 2011 (Fig. 3d-e), when there was the maximum precipitation in this area and the daily air temperature was highest (Fig.1). In August the temperature was higher than $21^{\circ} \mathrm{C}$, the cambium still kept a vigorous activity and 5-6 layers cambium cells were watched in Table 1 and Fig. 3f. After August, the daily air temperature started to fall (Fig. 1 ), the cambium activity weakened gradually and cambium cells layers became small, for exmple, 4-6 cell layers in September (Table 1 and Fig. 3g) and 3-5 layers in October. It was seen that the cambium activity became clearly weak in Octobe although it was higher than $11^{\circ} \mathrm{C}$. It began to turn to dormancy stage in November 2011 (Fig. 3j, 3k), when the air daily temperature below $10^{\circ} \mathrm{C}$ was appeared (Table 1). The cambium activity was consistent to the change of rainfall and the daily air temperature. From August the rainfall in wuhan clearly decreased and precipitation was below $50 \mathrm{~mm}$. The number of cell layer in cambium and the daily average temperature changed significantly in the whole active stage (Fig. 2). The change pattern of their curves were nearly the same. This reflected that a positive correlation was existed between the daily average temperature (x) and the number (y) of cell layer in cambium. Their equation was $y=0.1348 x+1.773 \quad\left(r=0.8627>r_{0.01}=0.7650\right.$, $\mathrm{n}=10,0<\times<37$ ). The climate factors, such as the daily average temperature and precipitation, had a great influence on the cambial activity (Fig. 2)

\section{Differentiation of xylem}

In the early April, there were 1-2 layers immature xylem cells next to the immature vessel and wood fiber cells (Fig. 3a). The number of cell layer in immature xylem cells were increasing before mid June and reached the maximum (14.55 layers) in June, then it gradually reduced, reaching 1-3 layers in mid Novem-

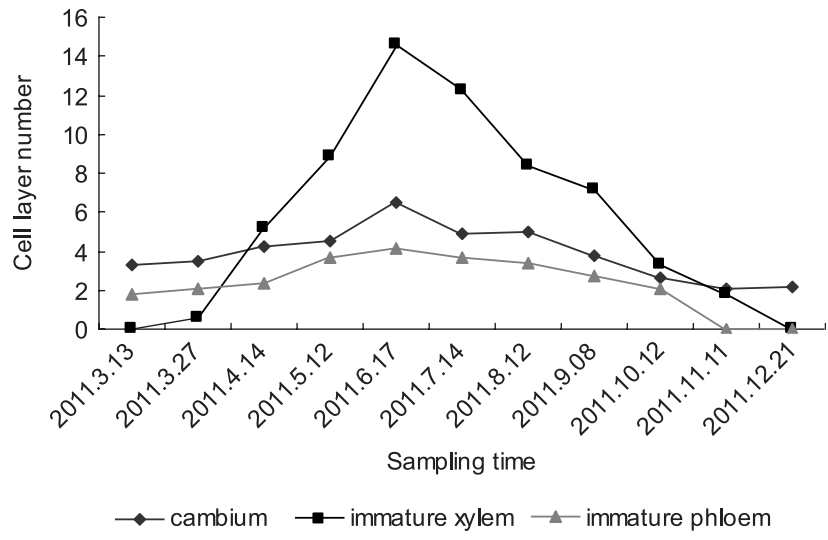

Fig. 4 Dynamic changes of cell layer number in cambium zone, immature xylem and immature phloem

ber and immature xylem could not be caught sight of in late December (Fig. 4). It seemed to suggest that the xylem cell had completed lignification process (Fig. 3k). The mature wood fiber cells and vessel with multiple secondary wall thickening could be observed at the mid May (Fig. 3c). The number of cell layer in xylem cells increased dramatically since the mid April, reaching a stable state until early June with 22.1 layers (Fig. 5). The immature xylem cells stopped increasing after October and the number of cell layer in xylem cells was stable at 28 layers (Fig. 5).

\section{Differentiation of phloem}

In the middle of March, phloem cells started to reactivate. In April, the sieve tube could be observed in phloem (Fig. 3a). The mean number of cell layers in immature phloem was 2.46. In early May, mature phloem started to appear. In the cambial active stage, the number of cell layer in phloem cells increased gradually, reaching the maximum of 8 layers in October (Fig. 5). In early November, the cambium could not produce new immature phloem cells any more (Fig. 4).

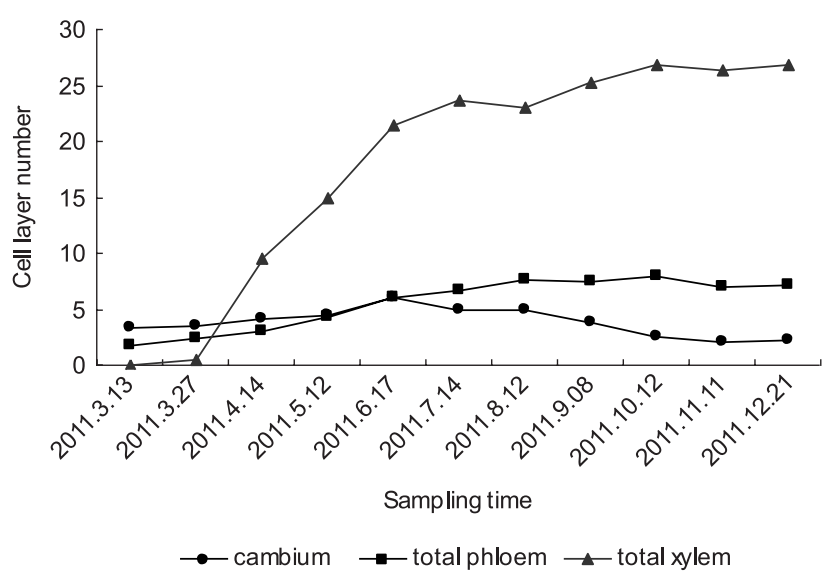

Fig. 5 Dynamic changes of cell layer number in cambial zone, total xylem,total phloem 


\section{Discussion}

To the majority of diffuse porous wood and semiring porous wood, the cambium reactivation had a great relationship with the activity of buds (Venugopal \& Liangkuwang, 2007). It was found that the cambial reactivation of camphor trees was obviously observed in the early March, one week after the onset of bud breaking in late February. It was similar to the studies of subtropical climate tree Dillenia indica (Venugopal \& Liangkuwang, 2007). The different characteristic could be observed in Fagus sylvatica (Čufar et al., 2008), which the cambium started to reactivate a week or a few weeks before the buds sprout.

The cambium activities had obvious periodicity, and there was a big difference among different tree species (Derr \& Evert, 1967; Farrar \& Evert, 1996; Chen et al., 2010). The time of reactivation, activating, and dormancy of cambium in camphor tree were studied in relation to the variation in the climatic factors such as temperature and rainfall. The cambial activity continued for eight months from March to October and the dormancy stage was from November to February. During winter (dormancy stage), the cambium cells consisted of only 2-3 layers, but the number of cell layers in cambium ranged from 3-7 in the active stage. The cambium area cells reached a maximum of 5-7 cell layers in June and July, and high temperature was in July and August and the rainfall were sufficient in this period in Wuhan, which suggested there was a positive correlation between the temperature and cambial cell layers in 2011. In March, the rising temperature played an important role in promoting the cambium to reactivate. Similarly, turning into dormancy of its cambium activity had more to do with the short day and low temperature in October. The similar research was reported in Ficus rumphii (Ajmal, 1987), Abies balsamea (Mellerowicz et al., 1992a,b), Norway spruce (Gričar et al., 2007b). The cambial activity in Dillenia indica, growing in subtropical wet forest of Northeast India, was influnced by seasonal temperature cycles (Venugopal \& Liangkuwang, 2007). Rossi (2008) found that at a temperature of $4-5^{\circ} \mathrm{C}$ (minimum temperature) and $8-9^{\circ} \mathrm{C}$ (average temperature), conifers started with a number of physiological process and xylogenesis. Except the temperature factor, our study indicated that the cambial activities were also affected by rainfall. In June to August, the rainfall was sufficient and the number of cell layer in cambium reached the maximum (5-7). Rao's study suggested that rainfall was probably an important factor only in the regions where the soil moisture content was dependent on rainfall (Rao \& Rajput, 2001).

The way of cambium activity determines the formation and distribution of secondary tissues. After the reactivation of cambium in camphor trees, phlo- em started to differentiate in mid March and then the differentiation of xylem was three weeks later. This was similar to the differentiation way about Ficus rumphii (Ajmal, 1987), which producing phloem first. In Pinus sp., like Picea mariana, Abies balsamea, and Larix laricina, phloem differentiation could occur for more than a month earlier than xylem (Alfieri \& Evert, 1968,1973). In our studies, phloem and xylem stopped differentiating in succession after entering the dormancy stage in October. In the whole differentiating process, the number of cell layers in phloem and xylem increased dramatically and increment of xylem was even more significant. Radial increment of xylem was almost fifth times of phloem in 2011. In June, the cell layers both reached the maximum. The appropriate temperature and sufficient rainfall in this period at this site largely facilitated the cell production. This was alike to the findings of Araucaria angustifolia, a combination of day length and temperature was the major environmental factor determining secondary growth seasonality (Oliveira et al., 2009). The study of Abies alba and Picea abies illustrated that the environmental influence on the formation of phloem was less than that on the xylem. Formation of phloem might be affected by more internal factors (Gričar \& Čufar, 2008).

The internal signals of trees and their growing environmental factors regulate cambial activity (Carlo, 2013). To camphor trees, the dynamic changes of vascular cambium and its derivative tissues are closely related to the phenology and climate in a growing season. Our research provide first-hand information of camphor trees in its seasonal dynamics of cambial activity in Wuhan district, the formation of xylem and phloem and for others with a strong seasonally related growth in general. Camphor trees grow in such a large areas in South China. For future researcher should be tended on the cambial activity pattern influenced by its provenance, different environmental factors (such as latitude and longitude,etc) and forest management in a great ecological districts.

\section{Acknowledgements}

This paper is a part of projects supported by National Natural Science Foundation of China (31170526 and 31570551).

\section{References}

Ajmal S \& Iqbal M (1987) Seasonal rhythms of structure and behavior of vascular cambium in Ficus rumphii. Annals of Botany 60: 649-656.

Alfieri FJ \& Evert RF (1968) Seasonal development of the secondary phloem in Pinus. American Journal of Botany 55: 518-528. 
Alfieri FJ \& Evert RF (1973) Structure and seasonal development of the econdary phloem in the Pinaceae. Botanical Gazette 134: 17-25.

Antonova GF \& Stasova VV (2006) Seasonal development of phloem in Scots pine stems. Russian Journal of Developmental Biology 37: 306-320.

Callado C, Neto SDS, Scarano F \& Costa C (2003) Periodicity of growth rings in some flood-prone trees of the Atlantic Rain Forest in Rio de Janeiro, Brazil. Trees 15: 492-497. doi:10.1007/s00468001-0128-4.

Carlo S, Alessio G, Luca S \& Tommaso A (2013) Hormonal signals involved in the regulation of cambial activity, xylogenesis and vessel patterning in trees. Plant Cell Reports 32: 885-898.

Chen HM, Han JJ, Cui KM \& He XQ (2010) Modification of cambial cell wall architecture during cambium periodicity in Populus tomentosa Carr. Trees 24: 533-540.

Čufar K, Prislan P \& Gričar J (2008) Cambial activity and wood formation beech(Fagus Sylvatica) during the 2006 growth season. Wood Research 53: $1-12$.

Čufar K, Cherubini M, Gričar J, Prislan P, Spina S \& Romagnoli M (2011) Xylem and phloem formation in chestnut (Castanea sativa Mill.) during the 2008 growing season. Dendrochronologia 29: 127-134.

Dave YS \& Rao KS (1982) Seasonal activity of the vascular cambium in Gmelina arborea Roxb. IAWA Bulletin 3: 59-65.

Deluis M, Gricar J \& Cufar K (2007) Seasonal dynamics of wood formation in Pinus halepensis from dry and semi-arid ecosystems in Spain. IAWA Journal 28: 389-404.

Derr WF \& Evert RF (1967) The cambium and seasonal development of the phloem in Robinia pseudoacacia. American Journal of Botany 54: 147-153.

Deslauriers A, Morin H \& Begin Y (2003) Cellular phenology of annual ring formation of Abies balsamea in the Quebec boreal forest (Canada). Canadian Journal of Forest Research 33: 190-200.

Eilmann B, Zweifel R, Buchmann N, Fonti P \& Rigling A (2009) Drought induced adaptation of xylem in Scots pine and pubescent oak. Tree Physiology 29: 1011-1020.

Evert RF \& Deshpande BP (1970) An ultrastructural study of cell division in the cambium. American Journal of Botany 57: 942-961.

Farrar JJ \& Evert RF (1996) Seasonal changes in the ultrastructure of the vascular cambium of Robinia pseudoacacia. Trees 11: $191-202$.

Fonti P, von Arx G, Garcia-Gonzalez I, Eilmann B, Sass-Klaassen U, Gartner H \& Eckstein D (2010) Studying global change through investigation of the plastic responses of xylem anatomy in tree rings. New Phytologist 185: 42-53.
Gričar J, Zupančič M, Čufar K \& Oven P (2007a) Wood formation in Norway spruce studied by pinning technique and intact tissue sampling method. Wood Research 52: 1-9.

Gričar J, Zupančič M, Čufar K \& Oven P(2007b) Regular cambial activity and xylem and phloem formation in locally heated and cooled stem portions of Norway spruce. Wood Science and Technology 41: 463-475.

Gričar J \& Čufar K (2008) Seasonal dynamics of phloem and xylem formation in Silver fir and Norway spruce as affected by drought. Russian Journal of Plant Physiology 55: 538-543.

Gričar J, Krže L \& Čufar K (2009) Number of cells in xylem, phloem and dormant cambium in silver fir (Abies alba Mill.) in trees of different vitality. IAWA Journal 30: 121-133.

Gričar J \& Jagodic S (2014) Can the structure of dormant cambium and the widths of phloem and xylem increments be used as indicators for tree vitality? European Journal of Forest Research 133: 551-562.

González-González BD, García-González I \& Vázquez-Ruiz RA (2013) Comparative cambial dynamics and phenology of Quercus robur L. and Q. pyrenaica Willd. in an Atlantic forest of the northwestern Iberian. Trees 27: 1571-1585. doi: 10.1007/s00468-013-0905-x.

Krepkowski J, Brauning A, Gebrekirstos A \& Strobl S (2011) Cambial growth dynamics and climatic control of different tree life forms in tropical mountain forest in Ethiopia. Trees 25: 59-70.

Mäkinen $\mathrm{H}$, Seo JW, Nöjd P, Schmitt U \& Jalkanen R (2008) Seasonal dynamics of wood formation: a comparison between pinning, microcoring and dendrometer measurements. European Journal of Forest Research 127: 235-245. doi: 10.1007/ s10342-007-0199-x.

Marcati CR, Angyalossy V \& Evert RF (2006) Seasonal variation in wood formation of Cedrela fissilis (Meliaceae). IAWA Journal 27: 199-211.

Marion L, Gričar J \& Oven P (2007) Wood formation in urban Norway maple trees studied by the micro-coring method. Dendrochronologia 25: 97-102.

Mellerowicz EJ, Riding RT \& Little CHA (1992a) Periodicity of cambial activity in Abies balsamea. I. Effects of temperature and photoperiod on cambial dormancy and frost hardiness. Physiologia Plantarum. 85: 515-525.

Mellerowicz EJ, Riding RT \& Little CHA (1992b) Periodicity of cambial activity in Abies balsamea. . Effects of temperature and photoperiod on the size of the nuclear genome in fusiform cambial cells. Physiologia Plantarum. 85: 526-530.

Ohashi Y, Sahri MH, Yoshizawa N \& Itoh T (2001) Annual rhythm oxylem growth in rubberwood 
(Hevea brasiliensis) trees grown in Malaysia. Holzforschung 55: 151-154.

Oladi R, Pourtahmasi K, Eckstein D \& Bräuning A (2011) Seasonal dynamics of wood formation in Oriental beech (Fagus orientalis Lipsky) along an altitudinal gradient in the Hyrcanian forest, Iran. Trees 25: 425-433.

Oliveira JM, Santarosa E, Pillar VD \& Roig FA (2009) Seasonal cambium activity in the subtropical rain forest tree Araucaria angustifolia. Trees 23: 107115. doi: 10.1007/s00468-008-0259-y.

Rao KS \& Rajput KS (2001) Relationship between seasonal cambial activity, development of xylem and phenology in Azadirachta indica growing in different forests of Gujarat State. Annals of Forest Science 58: 691-698.

Rossi S, Deslauriers A, Gricar J, Seo JW, Rathgeber CBK, Anfodillo T, Morin H, Levanic T, Oven P \& Jalkanen R (2008) Critical temperatures for xylogenesis in conifers of cold climates. Global Ecology and Biogeography 17: 696-707.

Schmitt U, Jalkanen R \& Eckstein D (2004) Cambium Dynamics of Pinus sylvestris and Betula spp. in the Northern Boreal Forest in Finland. Silva Fennica 38: 167-178.

Schweingruber FH (1988) Tree rings: basics and applications of dendrochronology. D. Reidel Publishing Company, Dordrecht, pp. 95-141.

Tucker MC \& Ray FE (1969) Seasonal development of the secondary phloem in Acer negundo. American Journal of Botany 56: 275-284.

Venugopal N \& Liangkuwang MG (2007) Cambial activity and annual rhythm of xylem production of elephant apple tree (Dillenia indica Linn.) in relation to phenology and climatic factor growing in subtropical wet forest of north-east India. Trees 21: 101-110.

Worbes M (1999) Annual growth rings, rainfall-development growth and long-term growth patterns of tropical trees from the Caparo Forest Reserve in Venezuela. Journal of Ecology 87: 391-403.

Worbes M, Staschel R, Roloff A \& Junk WJ (2003) Tree ring analysis reveals age structure, dynamics and wood production of a natural forest stand in Cameroon. Forest Ecology and Management 173: 105-123. doi:10.1016/S0378-1127(01)00814-3. 